\title{
Grande SERTÃo: VEREDAS, NOVE nOITES E A CONSTRUÇÃo DO 'EU' ATRAVÉS DO 'OUTRO'
}

Renan Augusto Ferreira BOLOGNIN*

Rejane Cristina ROCHA**

\section{RESUMO}

Em Grande Sertão: Veredas (1962), o narrador Riobaldo alude a um interlocutor que escuta sua narração. Em Nove Noites (2002), de Bernardo Carvalho, um dos narradores, Manoel Perna, realiza um procedimento semelhante ao endereçar sua narração a um interlocutor que não conhecemos igualmente. Assim, há um ponto de contato entre a narração de ambos os romances do qual advém a formação da identidade individual pelo contato com a alheia. Neste artigo discutiremos este ponto de contato a partir do 'ponto de sutura', de Stuart Hall, e apresentaremos os efeitos depreendidos dessas interlocuções a partir de uma base teórica narratológica.

Palavras-chave: Grande Sertão, Veredas, Nove Noites, Memórias, Identidade Cultural, Literatura Brasileira.

\section{INTRODUÇÃO}

No sertão, o homem é o eu que ainda não encontrou um tu (ROSA, 2009, p. 54).

Ser ou não ser. Eis o problema (SHAKESPEARE, 1996, p. 48).

Tupi, or not tupi that is the question (ANDRADE, 1976, p. 3).

O sertão é do tamanho do mundo (ROSA, 2001, p. 89).

* Mestrando do Programa de Pós-graduação da Universidade Federal de São Carlos (UFSCar), São Carlos, São Paulo, Brasil. E-mail: renanbolognin@hotmail.com

** Professora titular do Departamento de Letras da Universidade Federal São Carlos e do Programa de Pós-graduação em Estudos de Literatura da mesma universidade (UFSCar), São Carlos, São Paulo, Brasil. E-mail: rjncris@gmail.com 
Este artigo aproxima Grande Sertão: Veredas (1956), de João Guimarães Rosa, a Nove Noites ${ }^{I}$ (2002), de Bernardo Carvalho. Tal aproximação é de âmbito estrutural, enfatizando questões relativas à interlocução entre o narrador e o narratário nas duas obras. Assim, demonstraremos o procedimento narrativo adotado na construção de um 'interlocutor apagado'2 e os efeitos de sentido depreendidos.

O enredo de $G S V$ é construído na prosa de Riobaldo e de um interlocutor chamado de 'doutor' e 'senhor'. Nesta prosa, Riobaldo conta seu passado como criança de um local inespecífico do Brasil: o sertão. Ao aliar a narração a este lugar inespecífico, o leitor é convidado a entrar em uma história labiríntica. Isso porque Riobaldo conta sua infância; de quando conhecera a Diadorim (o amor de sua vida); de outros amores (Nhorinhá e Otacília); do período como "docente" de Zé Bebelo; quando partira para o sertão junto aos jagunços de Joca Ramiro (pai de Diadorim) para ficar perto de seu grande amor; quando Hermógenes assassina o chefe Joca Ramiro; e, por fim, algumas passagens obscuras que levam a crer que Riobaldo tenha feito um pacto com o diabo nas enigmáticas Veredas Mortas. Se houve pacto ou não, não se sabe. Mas Riobaldo assume a posição de chefe do grupo de Zé Bebelo (ex-grupo de Joca Ramiro) e chega ao confronto final com Hermógenes no qual o 'vilão' e Diadorim saem feridos a ponto de morte. Se não um dos finais mais tristes da literatura brasileira, pelo menos um dos mais enigmáticos: Riobaldo conta ao doutor ter descoberto que Diadorim, na verdade, era uma mulher vestida de jagunço.

O enredo de $N N$ baseia-se no porquê de um promissor antropólogo estadunidense, chamado Buell Halvor Quain, suicidar-se durante seu período de estudos in loco da tribo dos índios Krahô, na noite de 2 de agosto de 1939. Nesta obra há dois narradores: um jornalista inominado e um engenheiro, Manoel Perna. O jornalista interessa-se pelas razões do suicídio do americano a partir de uma notícia de jornal de 12 de maio de 2001, quase 62 anos após o suicídio. Para tentar desfazer sua obsessão, ele recorre a documentos que possam ajudá-lo na resolução do misterioso suicídio, tais como cartas, fotos da época e relatos de pessoas que tenham convivido com o antropólogo. Na outra instância narrativa, acompanhamos em itálico a narração de um testamento supostamente deixado por Manoel Perna, contemporâneo de Quain e 
morto em 1946. Nele aparecem com frequência os misteriosos dizeres "Isto é para quando você vier..." incitando um destinatário conhecedor do motivo do suicídio do antropólogo. Portanto, a interlocução é intrigante pelo fato de Manoel Perna dirigir-se a um destinatário - um interlocutor apagado - que supostamente viria em busca do testamento. Além disso, por vezes, este testamento parece um convite feito ao leitor para que participe efetivamente da diegese.

Fica patente, também, que os romances fazem um apelo à memória e ao contato com o 'Outro'. Para demonstrarmos isso, recorremos a uma base narratológica e, assim, damos ênfase às funções de analepse e de narratário. O primeiro destes termos é responsável por um movimento narrativo que dá conta de trazer memórias à tona, não como os acontecimentos do passado, mas reinterpretando-os. Já o segundo termo diz respeito, sobretudo, ao contato do 'eu' com o 'ele' na narração, o 'Outro'. Neste jogo de 'pessoas sintáticas', vê-se representado um jogo de diferenças basilar nas questões identitárias. Afinal: "A memória [...] tem algo a ver não só com o passado, mas também com a identidade e, assim (indiretamente), com a própria persistência no futuro" (ROSSI, 2010, p. 24).

Consideramos a identidade não apenas como função egocêntrica de um sujeito. Pensamo-la, sobretudo, em condições culturais: 'onde' 'como' e a 'quem' se enuncia demonstram a focalização ${ }^{3}$ da história contada, isto é, a ideologia dos narradores. Partindo disso, tentaremos responder a questões subjacentes nesses dois romances postos em comparação: quais são os efeitos depreendidos dos interlocutores apagados em ambos os romances? Como eles se aproximam e como se distanciam?

Tanto Riobaldo, quanto os narradores de $N N$ - em que merece destaque Manoel Perna - são 'eus' que buscam 'tus' para o estabelecimento/ consolidação de suas identidades, tal qual a primeira epígrafe deste artigo sugere. Adiantamos que, nos dois romances, lidamos com dois narradores sertanejos. Riobaldo, narrador de GSV, mantém interlocução com um "doutor". Já Manoel Perna tenta a interlocução com algum leitor (Nós, leitores virtuais, seríamos esse leitor? Ou ele endereça sua narração a um interlocutor em específico?) e, de algum modo, sua escrita truncada e rebuscada se aproxima desse "doutor": seja pela 
interlocução, seja pelo rebuscamento que parece exigir um leitor que tenha domínio de tal leitura.

Da interlocução entre Riobaldo/ "doutor" (sendo que este último não possui voz em GSV) e entre Manoel Perna/ "leitor", há dois movimentos: $1^{\circ}$ Há contato entre duas culturas que parecem embater-se, chocar-se. Ainda assim, a narrativa é construída, seja por Riobaldo, seja por Perna. Nessa construção, uma delas parece tomar a frente da voz narrativa e, assim, emergir no discurso. Desse modo, o segundo movimento parece-nos decorrência do primeiro: $2^{\circ}$ Quando estas vozes adentram o discurso, representantes de uma identidade não apenas una e egocêntrica, demonstram a tentativa de estabelecimento de uma identidade cultural. Se nos permitirem aliar a conclusão à introdução (nossa prolepse), isto explica a insistência de Riobaldo a tratar seu interlocutor por "doutor" (Médico? Advogado? Professor doutor?) e a escrita de um testamento em tom pedante pelo sertanejo Manoel Perna.

É na linguagem que se dão os maiores entraves. É nela que a formação do "eu" é constantemente abalada pelo choque com o "Outro". Ou podemos dizer pelo contato? Em seguida, apresentamos uma análise comparada que tratará da ênfase à interlocução nos romances como sintomático da construção da identidade identitária dos narradores.

\section{NARRAdOR E NARRATÁRIO: A FORMAÇÃo DA IDENTIDADE}

O interlocutor de Riobaldo em $G S V$ aparece na primeira página do romance pelo vocativo 'senhor': "Nonada. Tiros que o senhor ouviu foram de briga de homem não, Deus esteja (p. 23, grifo nosso)”. Já o de $N N$ parece mesclar-se com o leitor extralinguístico (virtual): “1. Isto é para quando você vier" (NN, p. 7, grifo do autor), também na primeira página. Nitidamente, o ponto de contato destes dois romances é a interlocução.

Curiosamente, o narratário de Riobaldo nunca lhe diz nada:

Então? Que diga? Doidera. A fantasiação. E, o respeito de dar a ele assim esses nomes de rebuço, é que é mesmo um querer invocar que ele forme forma, com as presenças $(G S V, 2001$, p. 25, grifo do autor). 
Ele é formado pela voz do 'Outro', a de Riobaldo, como a expressão "Que diga" sugere a resposta do interlocutor na própria voz do sertanejo. Assim também ocorre no testamento de Manoel Perna: "Desde então eu o esperei, seja você quem for" (NN, p. 12). Desse modo, paira no ar o porquê de os interlocutores sempre serem 'calados' pelos narradores. Em GSV, a conversa parece um solilóquio. Em $N N$, a interlocução desemboca na clara busca por um interlocutor que viria atrás do porquê do suicídio de Quain. Uma busca por um "narratário escondido na diegese" faz com que nós, leitores, nos sintamos capacitados a ingressar no romance como partícipes da narrativa. Ainda que sejamos sempre partícipes na narrativa como leitores, como comenta Umberto Eco em seus Seis passeios pelo bosque da ficção (1994, p. 9-14), esta participação torna-se mais direta em $N N$, pois o "eu" conquista o leitor com seus apaixonantes, e reiterados, "Isto é para quando você vier". Assim, num jogo linguístico audaz, ficção e realidade misturam-se.

Ainda assim, responder o porquê do suicídio, posto no parágrafo anterior, parece impossível. É mais factível perceber que ambos os romances proporcionam uma leitura labiríntica devido ao acento diacrítico que propõem às relações humanas, da qual emana o contato com o 'Outro', e é refletido na estrutura narrativa. Isto é, Riobaldo e Manoel Perna demonstram o homem em seu imprescindível contato com o 'Outro'. Não existe o 'eu' sem o 'Outro'. O cavalo e o 'ele' foram as maiores conquistas do homem (GREIMAS apud BERTRAND, 2003, p. 107). Sem o 'ele' qualquer conquista do 'eu' seria dificultosa. Até mesmo incompleta.

Por isso mesmo, em entrevista a Günter Lorenz, João Guimarães Rosa (2009) aclara que não é um escritor de romances, mas um "contista de contos críticos" (p. 309). Obviamente, nenhum tema crítico é suplantado somente na ficção. Isto é, a sua ficção poética é endossada com a realidade, tal qual se pode verificar em $N N$.

Pelo caráter crítico proveniente desse contato, que forma o 'eu' a partir do 'Outro', evidencia-se um contato mais amplo. Referimo-nos, obviamente, ao contato entre as diversas classes sociais e as identidades delas postas em jogo: "Mas, não diga que o senhor, assisado e instruído, que acredita na pessoa dele?! Não? Lhe agradeço! Sua alta opinião 
compõe minha valia" (GSV, 2001, p. 26). A opinião de Riobaldo só é confirmada pela do doutor, embora a voz deste sempre esteja embutida na do sertanejo. Desse modo, as memórias de Riobaldo só têm existência a partir do 'Outro'.

Ainda assim, o doutor é emudecido como num movimento político que demonstra a força da voz de Riobaldo. Afinal, Riobaldo é o homem do sertão, produzido pelo lugar, não o doutor: "[...] os homens, por sua vez, são produzidos pelo meio físico" (CANDIDO, 2009, p. CXLIX). Como sugere Luiz Roncari (2004, p. 203), há dois sertões: um interno e um externo. Isto é, há o sertão da interioridade do homem e o do lugar, que transferem impulsos significativos um ao outro. Portanto, a diferença entre Riobaldo e o doutor perfila-se na dialética entre quem é e quem está no lugar. Obviamente, esta é uma diferença hierárquica vertical, que põe Riobaldo acima do doutor. Uma virada de mesa. Afinal de contas, quando a experiência do homem do sertão é posta em evidência (não necessariamente a do analfabeto, afinal Riobaldo destrói qualquer estereótipo de que todo sertanejo seja iletrado) emudece a do doutor. Neste caso, emudece, metaforicamente, o urbanizado, o letrado, a classe alta.

Em $N N$ temos a impressão de que o interlocutor de Perna chegará e solucionará o caso de Quain. Esperança vã. Sua escrita é acima de tudo uma demonstração clara de um homem que acomoda seu contar a alguém que lhe é hierarquicamente superior. $\mathrm{Na}$ instância de outro narrador do romance, vemos um ponto de identificação entre ambas. Pelo ponto de vista do jornalista demonstra-se todo o desprezo cultural em relação aos povos indígenas ao não querer participar das celebrações Krahôs em:

A mais debochada, Gersila Kryjkwỳi, estava inconformada com a minha desfeita. Eu respondia que não me sentia à vontade para ser batizado, só estava na aldeia havia três dias, mas jurei que da próxima vez as deixaria fazer o que bem entendessem comigo. Gersila gritava que sabia muito bem que não haveria próxima vez, eu era um frouxo. Creuza Prumkwỳi sentenciou que então ela ia esperar, porque da próxima vez que eu pisasse na aldeia ia me batizar como manda o figurino, ia me arrancar cada um dos cílios, além das sobrancelhas, ia tirar sangue de $\operatorname{mim}(N N$, p. 106-107). 
A cultura indígena é posta como exótica, num movimento que a nega. Ao leitor acostumado com uma visão unidirecional à própria cultura, os costumes de arrancar cílios e sobrancelhas em um batismo de ingresso a uma nova "família indígena" podem soar como uma violência tremenda, responsável por gerar um distanciamento. Uma não identificação étnica. No fundo, o narrador deseja que entremos em contato com ele e, por conseguinte, estejamos de acordo com ele. Vejamos pelos olhos dele.

$\mathrm{Ou}$, para os mais intransigentes entenderem, isto é um elogio à não transgressão da focalização do narrador como não transgressão da visão de uma classe. Consequentemente, a focalização da vida cultural indígena desloca-se em direção aos mistérios que permeiam Quain e identifica-se nos dois narradores do romance. Ou seja, o estrangeiro é narrado em detrimento à etnia autóctone do país. Num movimento contrário ao de $G S V$, em $N N$ há a demonstração clara de diferenças étnicas que são postas à margem. Neste caso, tratamos do emudecimento das etnias menores, postas hierarquicamente à margem.

Em comum, topamos com a memória sustentando a estrutura narrativa dos dois romances. Em ambos, ela funciona de modo a recuperar um passado. Em $G S V$, ela é a recuperação de um passado individual, que para ser contado depende do 'Outro'. Em $N N$, o passado depende do 'Outro' também, mas é buscado em forma arquivística.

Referimo-nos a questões arquivísticas como procedimento utilizado para a estruturação memorialística de $N N$ enquanto texto literário. Isto é, embora haja informações sobre o suicídio de B. Quain e outras referências históricas como o Estado Novo varguista e o 11 de setembro, nada nos impele a relacioná-lo a uma tentativa de reconstrução da realidade histórica. Em "Metaficção historiográfica: O passatempo do tempo passado", do livro Poética do pós-modernismo, Linda Hutcheon (1991, p. 152) enfatiza a escrita literária pós-moderna por intermédio dos documentos/arquivos do passado. Assim, o conceito de metaficção historiográfica tange a problemática mnemônica da história. Isto é, o enredo literário é construído a partir do questionamento e do aproveitamento dos 'detalhes' tidos como verdadeiros e/ou falsos do que conhecemos sobre o passado. Desse modo, a história é posta em cena enquanto construção discursiva e ideológica, a partir de interesses que a 
transvestem com uma roupagem retórica adequada aos dizeres da classe que a enuncia. Isto é, esta realidade histórica é construída pelas estruturas do romance e é perceptível, sobretudo, na bipartição narrativa e nos vaivéns temporais que dão o efeito de incompletude do passado histórico nos arquivos escassos sobre Quain.

Assim, a busca pelo 'Outro' por meio de documentos a respeito de Quain é uma construção discursiva, pois a pessoa já não responde por 'eu', mas por 'ele'; o tempo já não é o 'agora', mas o 'antes'; e o lugar não é mais o 'aqui', mas o 'lá'. Além do mais, não há testemunhas. E, mesmo se houvesse, como o passado testemunhado é linguístico e, também, discursivo, é trazido à tona a partir de interesses ideológicos da testemunha. É um passado da linguagem, não do corpo (SARLO, 2007). Destarte, Quain é referido de maneira nebulosa no romance, pois a forma de trazê-lo à tona pela linguagem, de certa forma, também é.

Daí, uma dialética entre memória voluntária/involuntária demonstra a diferença básica entre buscar o passado e vê-lo como um insight ${ }^{4}$. No entanto, a diferença entre contar algo experimentado e algo pesquisado resulta em diferenças abissais para um pacto fiduciário a respeito do passado. Em $G S V$ narra-se uma memória que significa toda a existência de Riobaldo. Em $N N$ a memória é uma busca pelas inconclusões da existência do 'Outro'. Em comum, os narradores reconstroem essas histórias como se não as ressignificassem na narração ${ }^{5}$. Ainda assim, isso é impossível, pois as memórias, quando narradas, são sempre ressignificadas. Em $G S V$, a ressignificação é perceptível a todo momento, pois a história de Riobaldo tem ares de ter sido repetida muitas vezes a outros interlocutores em virtude de sua carga oral. Já em $N N$ a ressignificação parece mais amena, pois o mote do romance, o suicídio, gira em torno de uma busca por documentos a respeito do passado. Evidentemente, estes documentos, ressignificam o passado, afinal de contas, são postos em conjunto com vistas à construção literária.

Em $G S V$ estamos diante de uma maneira dialogada de contar o passado e ligada a anacronias tão perceptíveis que cortam a narração para inserir histórias. Em $N N$, a essas digressões, relacionadas ao narrador principal, temos também o acréscimo de um testamento como documento histórico. No entanto, este documento é questionável. Ao 
passo que suas cordas se desafinam, afinam-se as da literatura. Isto é, há um embate entre literatura e história perceptível durante a leitura de $N N$. Ademais, uma fragmentação de Quain, pois ele está no 'entre-lugar' de literatura e história.

Curiosamente, o título do romance, faz lembrar Mnemosine, deusa grega da memória que passara nove noites com Zeus e dera à luz a nove musas ${ }^{6}$. Lembrando-nos dos deuses gregos, não podemos deixar de lado uma analogia com $G S V$ :

O senhor ache e não ache. Tudo é e não é... Quase todo mais grave criminoso feroz, sempre é muito bom marido, bom filho, bom pai, e é bom amigo-de-seus-amigos. Sei desses. Só que tem os depois - e Deus, junto. Vi muitas nuvens (GSV, 2001, p. 27-28).

$G S V$ já foi estudado sob essa perspectiva por Luiz Roncari (2004) em "As três cores do amor" n' O Brasil de Rosa. Desse modo, essa fragmentação do 'ele' em $N N$ não parece nova. Guimarães Rosa já havia feito uso dela, demonstrando-a também pela história fabulosa de GSV estar ancorada na figura de Ares e Afrodite, isto é, na guerra e no amor, respectivamente: “[...] Diadorim, atração de amor e guerra, como a confluência do próprio sertão, onde se junta e se mistura tudo, o ideal e o real, Deus e o diabo" (RONCARI, 2004, p. 213).

Isto é, há 'homem' de todo tipo dentro de um único. De maneira semelhante aos deuses, nos dois romances temos personagens balançados entre o bem e o mal. Tudo é e não é. Riobaldo, aliás, é seminal nesse pressuposto, já que a indefinição de seu pacto com o diabo e a ascensão a chefe do bando de jagunços parecem situações opostas, não pertencentes ao menino sertanejo que tinha medo de atravessar o São Francisco. É o contato com o 'Outro' o que desencadeia a indefinição do 'eu'. A mudança de apelido Tatarana a Urutu Branco demonstra como os narratários de Riobaldo (afinal, ele também é lido intratextualmente pelos outros personagens) agem por meio da língua para modificarem a identidade do personagem. No primeiro caso, associamos o nome de Riobaldo a um garoto medroso. A definição é possível pelo primeiro contato que ele tivera com Diadorim e deixa claro o paradoxo de idiossincrasias existente entre eles: este último é um que não carece de ter medo, não: “- 'Você nunca teve medo?' - foi o que me veio, de dizer. 
Ele respondeu: - 'Costumo não...'” (GSV, p. 122). Integrado ao grupo de Joca Ramiro, em razão de ter reencontrado o menino (Diadorim) que havia conhecido no rio de-Janeiro, Riobaldo é apelidado pelos outros jagunços como Tatarana. Sob a posse deste nome iniciático do grupo, Riobaldo demonstra querer ser Diadorim, ou pelo menos aproximar-se dele e de sua coragem. É a preparação à guerra a partir do amor de infância. No desenrolar, Riobaldo torna-se chefe dos jagunços a partir de um suposto pacto com o diabo nas Veredas Mortas. A alcunha de Urutu Branco, anteriormente dada vagamente por Zé Bebelo como nome de guerra (CANDIDO, 2009, p. 236-7), paira na convergência de Riobaldo com Diadorim. Riobaldo converte-se no chefe não só de Diadorim, mas do bando. Desse modo, a leitura que o bando de jagunços faz de Riobaldo não é mais horizontal, mas vertical. O apelido dado por Zé Bebelo assume significação plena unido às questões de caráter mágico que incidem em Riobaldo e permite que os jagunços o leiam em variância plurissignificativa.

E isso também ocorre com Quain: a presença dele se dá pela ausência ${ }^{7}$ e, consequentemente, seus atos são duvidosos. Entre o estudante promissor, encontram-se relatos de bebedeira e de possível homossexualidade. Mas tal fica pincelado pelo signo da incompreensão e do mistério. Afinal de contas, saber a bondade e a maldade é tarefa difícil tendo-se em mãos apenas alguns documentos transformados em romance.

Assim, a focalização em ambos os romances, sendo nebulosa e memorialista, contribui para tais dúvidas. Recuperar Diadorim, por completo, é, também, impossível. Por isso, só sabemos de seu "segredo" ao final do romance. São inconclusões jogadas da narração à narrativa, afinal de contas, só conhecemos Diadorim por intermédio de Riobaldo. Deste modo, conhecemos mais a Riobaldo, protagonista e organizador das informações narrativas do que a Diadorim, até porque a história do 'Outro' serve, também, como história de si mesmo.

Se nos detivermos numa aproximação de ambos os romances, veremos que "Tem coisa e cousa, e o ó da raposa (GSV, p. 47)". Aproximação, por si só, corajosa, pois trata de dois romances de construção técnica apurada. No entanto, necessária, afinal de contas, a memória é, também, em $G S V$ uma recorrência evidente à formação identitária de Riobaldo e de seu duplo Diadorim: é o homem no homem. 
Romance de amor entre opostos que são iguais. De ser e de não ser. De definições que não se resumem a um instante da visão. Nem se resolvem à exterioridade. Nem a anos de convivência. A vida, como o amor, é mais que isso: ela dá voltas em si, se trança e nos joga no sertão. E, para rever este amor, Riobaldo conta toda a história ao 'doutor'. É a tentativa de compreender/ reviver/ ressignificar este passado primoroso da vida. É o que Franklin de Oliveira (2009) professa:

O ideal que informa a arte de Guimarães Rosa é o do homem harmonioso. Ele sabia que o ser humano não se desenvolve por igual, nele ficando sempre amplos ares de sombra a serem iluminadas. De onde a perversidade, o crime - os seres incompletos, que povoam a sua ficção. Por isto, acreditava na salvação do homem, através do aperfeiçoamento da consciência individual (p. 158).

Primeiramente, como dita Franklin, parece-nos que Guimarães preocupou-se com essa ambiguidade de seus personagens, cujos destaques são Riobaldo e Diadorim. Mas um homem que é harmonioso porque alcançou um aperfeiçoamento de sua consciência individual soa idealista. Pensamos por outro viés. Um viés que enxerga na ambiguidade do personagem rosiano uma posição de 'descontrole' semântico enquanto reflexo da narração. Da mesma forma, percebemos a leitura de $N N$ pela visualização de Quain em um percurso não harmonioso com sua própria identidade. E não harmonioso pelo percurso ambíguo de uma avalanche de semas. Referimo-nos a isso a partir do ensaio seminal de Catherine Gallagher (2009) intitulado 'Ficção' no qual ela discute, principalmente, as categorizações das terminologias, também ambíguas, de romance e novela. Ainda nesse ensaio, a autora traça um panorama interessante sobre a personagem. Citamo-la de maneira diluída, a partir da categorização de personagem feita por Roland Barthes e comentada exaustivamente por ela: "[...] quando semas idênticos atravessam por diversas vezes o mesmo Nome próprio e parecem fixar-se, nasce uma personagem" (apud, p. 648).

A indefinição do etnólogo não ocorre apenas no conteúdo, mas também na forma pela qual os dados a seu respeito são levantados na narração. Com o prevalecimento da forma, as indefinições do passado mostram-se através dos signos técnico-narrativos que adéquam a pesqui- 
sa sobre o suicídio irresoluto na forma literária. Valendo-se de uma mudança focal recorrente, que vai da externalização da pesquisa à internalização de si mesmo, o narrador jornalista de $N N$ aumenta o espectro focal de Quain ao selecionar e integrar sua voz em cartas sobre o americano.

Somado a isso, a voz de Manoel Perna, o sertanejo, também é responsável por tirar o foco de Quain. Aliás, com este narrador, temos a forte tendência de construir, enquanto leitores, vários Quain distintos. Se recuperarmos a citação de Franklin de Oliveira e a transferirmos ao estudo de $N N$, notaremos que esse homem harmonioso também está ausente neste romance.

Afinal, o homem ambíguo, difuso, é matéria de como o narratário o percebe. E, por vezes, nós, seus leitores virtuais: "E, Diadorim, que vinha atrás de mim uns metros, quando virei o rosto vi meu sorriso nos lábios dele" (GSV, p. 579). Ou o Hermógenes, homem sem cara (p. 590), esvaziado pelo contato com o 'Outro'. Ou pelo interlocutor e sua imaginação.

As estruturas de ambos os romances sugerem isso. Se os olharmos panoramicamente, perceberemos que $G S V$ e $N N$ não estão divididos em capítulos. Isto é, nenhum deles está separado fixamente em capítulo $1,2,3$, etc. Há em $N N$, no entanto, indicações numeradas de 1 a 19 em alguns parágrafos, mas que não se autodenominam capítulos. E essa característica não é gratuita. O leitor mais atento perceberá isso como um caminho de leitura mais espinhoso, sobretudo quando se der conta dos vaivéns temporais e do passado sendo ressignificado na(s) voz(es) do presente. É justamente nestes textos alongados e de tempos misturados que a estrutura demonstra como os personagens constroem-se.

Por isso, não espanta Guimarães Rosa defender que o escritor seja ilógico:

O escritor, naturalmente, só o bom escritor, é um descobridor; o mau crítico é seu inimigo, pois é inimigo dos descobridores, dos que procuram mundos desconhecidos. Colombo deve ter sido sempre ilógico, ou então não teria descoberto a América. O escritor deve ser um Colombo (ROSA, 2009, p. 44).

A matéria narrativa para Guimarães Rosa deve ser ilógica para que o autor seja um descobridor de mundos desconhecidos. Descobri- 
dor dos lugares desconhecidos da própria língua, acrescentamos. Já Bernardo comenta sobre $N N$ que:

O livro foi escrito num momento em que eu estava muito irritado com essa ideia de que a ficção vale menos do que os livros baseados em histórias reais, o que é uma tendência muito forte no mundo todo. A literatura estava se tornando restrita e elitista (CARVALHO, 2011, p. 2).

Seja ilogicamente, seja no contato com o 'Outro', Bernardo Carvalho dá a medida exata para uma análise de como estas vozes vem à frente de outras: a hierarquia parece dominar a estilística de romances que converte a literatura em "restrita" e "elitista". Já não é o valor das histórias reais, pois isso já é totalmente rebatível mesmo ao falarmos sobre história. Seu ilogismo parte da presença de ficção na história e vice-versa. Conjugada desse jeito, sua obra permite contrastar vozes de camadas altas e baixas e, assim, descobrir os mundos desconhecidos do 'Outro'.

Desse modo, a forma literária de ambos os romances possui propostas estéticas semelhantes no tocante linguístico, sendo que é no ilogismo da construção estética que os personagens se juntam a tantas indefinições e identificações. Veja-se, por exemplo, o caso dos amores de Riobaldo num texto de Benedito Nunes (2009) intitulado $O$ amor na obra de Guimarães Rosa: em Otacília há uma espécie de "força como a paz", de uma "vida outra" e de uma visada espiritual; Nhorinhá é uma personagem semanticamente oposta à primeira: é o amor simples e natural, voluptuoso e sensual; Diadorim, no entanto, é o caminho do meio, o da paixão equívoca, do amor do Maligno, do primitivo e do caótico. Mas esse mundo é muito misturado e essas considerações são didáticas. Na verdade, esses amores, para Benedito Nunes, por vezes, se interpenetram.

Já Heloísa Vilhena de Araújo (1992, p. 96) aponta a figura de Diadorim como espelho ambíguo de Riobaldo. Nessa visão espelhada enxergamos os mecanismos focalizadores no contato entre o 'eu' e o 'ele' e como o narrador manipula suas informações narrativas. De como ele quer trazer à baila suas ressignificações do passado. $\mathrm{O}$ "eu" é formado pelo "ele", mas não deixa de fazer seu papel, formando todos esses 
amores na própria voz. Não há assujeitamento no contado. Diadorim seria diferente se coubesse em algum conceito e soubéssemos desde o princípio o que lhe acontece no final do romance. Não seria o amor ilógico mais e o contar perderia força.

Da mesma forma aconteceria em $N N$. Se chegássemos ao final idealizado e descobríssemos o porquê do suicídio de Buell Quain por meio de uma voz que é chamada e que nunca aparece, essa formação do 'eu' do narrador jornalista a partir do testamento de Manoel Perna estaria impossibilitada. Acabaria aí o ilógico desse romance.

"Diadorim, ser andrógino, é, ao mesmo tempo, divino e diabólico" (NUNES, 2009, p. 90) e sua androginia pode ser, também, alçada simbolicamente à indefinição do pacto com o diabo feito por Riobaldo. Coincidentemente, em $N N$, encontramos também a indefinição, representada, dessa vez, pela sexualidade de Buell Quain ${ }^{8}$.

Adentrando, novamente, na 'estrutura' dos dois romances nos perguntamos se essas indefinições não estariam retratando a maneira pela qual o 'eu' da narração organiza a narrativa. Tanto Riobaldo, quanto o narrador de $N N$, são tensionados a entrar nos rios profundos de suas experiências:

Assaz o senhor sabe: a gente quer passar um rio a nado, e passa; mas vai dar na outra banda é num ponto muito mais em baixo, diverso do que se pensou em primeiro. Viver não é muito perigoso? ( $G S V$, p. 51).

Pelo fato de Riobaldo contar histórias, ele depende do 'Outro'. É, portanto, esse contato com o doutor, o formador identitário dele(s), e da tentativa de cicatrização das feridas do passado. O 'Outro' é, então, o espelho do 'eu':

Ah, naqueles tempos eu não sabia, hoje é que sei: que, para a gente se transformar em ruim ou em valentão, ah basta se olhar um minutinho no espelho - caprichando de fazer cara de valentia; ou cara de ruindade! (GSV, p. 62).

Ser ou não ser é o duelo travado nas duas obras, como sugere a segunda epígrafe deste artigo. Não no sentido do príncipe dinamarquês Hamlet que pensa em matar-se ao pronunciar tão afamado monólogo. 
Mas o "ser ou não ser" é agora um "problema" em relação ao passado: "Moço, toda saudade é uma espécie de velhice" (p. 56). Algo a partir do qual o interlocutor, o narratário, se ressignifica. Ou de como o 'nós' (o 'eu + tu', o 'eu+ ela' e o 'eu+ ele') focaliza a história diferentemente.

Isso porque um não existe sem o outro. $\mathrm{O}$ 'ele' confronta o 'eu', o inquire, o julga. E desloca a identidade alheia. Às vezes convenientemente. Faz perguntarmo-nos "tupi or not tupi that is the question", isto é, faz-nos converter o anterior em algo novo por conta dos sentimentos do momento.

No caso a referência a Oswald de Andrade é pertinente, de nossa terceira epígrafe, por salientar um momento histórico e suas concepções antropofágicas. E, haja vista, um momento cultural influenciado pelo contraste com o passado e pelo uso dos valores do "Outro" para a construção artística do "aqui": assim também ocorre nos dois romances.

À guisa de interesses próprios, temos algo perto do que fora antes, mas o sentido já é outro. Isento de relações de valor. Mas plurissignificativo. Perguntamo-nos: qual é (já) a identidade de Riobaldo e a de Quain? ${ }^{9}$

A identidade é, então, aquela na qual se figuram os caminhos percorridos no passado. A experiência. Os narradores a utilizam para se fincarem na história por meio da narração. Ou seja, essa retomada do passado não deixa de ser o estabelecimento de uma identidade cultural na História. A narração é, então, o instrumento de maior fôlego que as identidades, sertanejas/ rurais e/ou metropolitanas, possuem. Afinal, essas só começam a se fixar quando postas em narração (RICOUER, 2007, p. 108) e tentam demonstrar o seu ponto de sutura ${ }^{10}$, como nos sugere Stuart Hall (1996, p. 5-6, grifo do autor, tradução nossa):

Eu uso 'identidade' para referir-me ao ponto de encontro, o ponto de sutura, por um lado os discursos e práticas com os quais se tenta 'interpelar', dizer-nos ou assimilar-nos a um lugar como sujeitos sociais de discursos particulares, e, por outro lado, os processos com os quais se produzem as subjetividades, onde construímo-nos como sujeitos que podem ser 'ditos'.

Ou seja, a identidade é um ponto de sutura pelo fato de aliar em si o choque constante entre o interior e o exterior num embate discursi- 
vo. É na narração que ela ocorre, afinal é a estória de uma determinada cultura num dado tempo e espaço físico.

José Carlos Garbuglio (2002) expõe em “Guimarães Rosa: O demiurgo da linguagem" um tratamento linguístico/estilístico da ficção rosiana no qual reside uma relação entre homem e palavra. $\mathrm{O}$ apagamento das impurezas dos vestígios originais da palavra é benéfico para a reconquista da confiança do homem nela (p. 171). Este é o primeiro ponto de intersecção da identidade com a narração, isto é, com o linguístico. O primeiro ponto de sutura (HALL, 1996, p. 5-6) que aproxima $N N$ e $G S V$. Afinal de contas, em ambos é na palavra confiada ao outro, numa narração fiduciária, em que se entrelaçam os dois romances.

Outro ponto de sutura é o de ambiguidade dos personagens. Riobaldo, garoto que atravessa o Rio São Francisco com Diadorim ( $G S V$, p.) é e não é o mesmo Riobaldo moço professor de Zé Bebelo ( $G S V$, p. 144); é e não é tatarana, jagunço do bando de Joca Ramiro; é e não é Urutu Branco (p. 354), chefe do bando; é e não é o narrador. Riobaldo é tudo isso e mais um pouco. Congruente a Quain de Nove Noites, Riobaldo é também um ser nublado. Um personagem que não se adéqua a definições. Onde o homem carece de ser uno, "Eu sou donde eu nasci. Sou de outros lugares" (GSV, p. 306). E Diadorim, duplo de Riobaldo, tem também suas maneiras de ser visto: é o jagunço amado por Riobaldo; o Reinaldo; e o Menino do Porto. E, da mesma forma, a visão de Riobaldo triparte seus amores na figura da Nhorinhá Dorme-comigo (p. 206), da Otacília (p. 172) “Casa-comigo" (p. 206) e de Diadorim, como dito anteriormente:

Só se pode viver perto do outro, e conhecer outra pessoa, sem perigo de ódio, se a gente tem amor. Qualquer amor já é um pouquinho de saúde, um descanso na loucura. Deus é que me sabe. O Reinaldo era Diadorim - Mas Diadorim era um sentimento meu (GSV, p. 327).

Este ponto levaria ao mesmo do exposto anteriormente, a menos que nos ativéssemos na maneira pela qual tais identidades, representadas pelas personagens e suas características, a partir do lugar. Mas não um lugar físico. Um lugar enquanto espaço social, principalmente. Isso porque o sertão é móvel: “[...] é onde os pastos carecem de fechos" (p. 24). E há dois sertões: um interior e um exterior. $\mathrm{Na}$ 
andança entre um e outro, salta aos olhos a conhecida discussão do conceito de travessia, trazida recorrentemente nas obras de Guimarães Rosa. Nas palavras de Luiz Roncari (2004), a travessia é o símbolo do homem em direção a seu infinito (p. 240). À transcendência do indivíduo, acrescentamos. Mas a travessia pode ser, também, social. Desse modo, as mudanças ocorridas na história tendem a transcender, também, o lugar. Assim sendo, o sertão é, guardadas as devidas proporções, a metáfora da globalização, pois abre caminho à indefinição de um local, seja territorial, seja temporal, afinal: "O sertão está em toda parte" (p. 24), assim como produtos globalizados nas estantes das lojas. Recuperando nossa quarta epígrafe: "O sertão é do tamanho do mundo" (ROSA, 2001, p.189).

Em $N N$ isso adquire um valor interessante nos movimentos globalizados de mundo sem fechos. Quain era, inegavelmente, um nômade global:

Ao terminar o ginásio, aos dezesseis anos, Buell já tinha atravessado os Estados Unidos de carro. Em 1929, antes de entrar para a universidade, passou seis meses na Europa e no Oriente Médio, percorrendo Egito, Síria e Palestina. Nas férias do ano seguinte, foi para a Rússia. Depois de prestar os exames, em fevereiro de 1931, embarcou numa viagem de seis meses, como marinheiro, num vapor para Xangai. Em 1935, estava em Nova York, e ano seguinte, em Fiji (NN, p. 18).

O narrador jornalista demonstra facilidade de locomoção: passa pelo Xingu, Rio, Paris e Nove Iorque com uma facilidade impressionante. Além disso, o ataque às torres gêmeas em 2001 parece metonímico em relação a toda a estrutura textual e ao enredo a partir do desmoronamento do 'lá' pelo do 'aqui'. Assim sendo, o 'lá' e o 'antes' afetam o 'aqui' e o ‘agora'. A busca do narrador por parentes distantes de Quain que poderiam solucionar o caso do etnólogo é emperrada. Deve-se isso ao acréscimo de antraz nas correspondências dos estadunidenses por parte de pessoas envolvidas ao ataque às torres gêmeas. Como poucas correspondências são respondidas ao narrador (de maneira incompleta), ele não descobre o que afligia a Quain. É inegável, portanto, que estes espaços indefinidos, também, ajam sobre a identidade. 
Já em Guimarães Rosa, o conceito de travessia, como passagem de um espaço a outro com contornos redentores, ganha força em comparação a Quain. Afinal, Riobaldo fez sua travessia e saiu de um estado inicial a um final no decorrer/interior das peripécias propostas durante o percurso de sua vida. A locomoção dessa travessia para Riobaldo já não importa enquanto fácil ou difícil, mas importa a contribuição trazida para o que ele se transformou: "Digo: o real não está na saída nem na chegada: ele se dispõe para a gente é no meio da travessia" (GSV, p. 80).

No mais, sertão e vida têm em comum a solidão: "Sertão é o sozinho. Compadre meu Quelemém diz: que eu sou muito sertão? Sertão: é dentro da gente" ( $G S V$, p. 325). O fato de comunicar-se com o doutor - demonstra que Riobaldo não é sozinho. Ele o é na medida em que o lugar incide nele, deixando-o sozinho. Todos necessitam expurgar seu passado. As histórias têm que ser contadas. Deixar o 'Outro' de lado é deixar a si mesmo.

Até porque a memória precisa restabelecer-se: “Agora, que mais idoso me vejo, e quanto mais remoto aquilo reside, a lembrança demuda de valor - se transforma, se compõe, em uma espécie de decorrido formoso" ( $G S V$, p. 359). E o lugar globalizado de $N N$ incide da mesma maneira no narrador principal do romance: o lá é o logo-aqui. Já o narrador Manoel Perna, também um sertanejo, mas com traços de doutor que possui voz - pois é também engenheiro - traça em sua escrita pernóstica um diálogo 'riobaldiano' em seu testamento, pois tenta a interlocução com alguém que não possui voz na narração. Ou seja, o mundo, nos dois romances, é muito misturado. Dentro deles cabe um pouco de tudo. Cabem identidades. Cabe o amor. Cabe a guerra.

\section{Considerações Finais}

No final, "No que narrei, o senhor talvez até ache mais do que eu, a minha verdade. Fim que foi" (GSV, p. 616) soa como chave de leitura para $N N$. O infinito, significativo na lemniscata da última página de $G S V$, se repete. Dessa vez, outro romance toma-a emprestada. Ao final de $N N$, descobrimos que outro americano vem ao Brasil para estudar nossas culturas indígenas. O fim abraça o começo. O infinito de Gui- 
marães Rosa se dá em $N N$ de maneira que o mundo vai e volta e, dessa vez, põe os olhos em etnias marginais de nossa cultura.

E tudo se (re)configura. Como olhamos o 'Outro'. E como o 'Outro' nos olha. Nesse entrechoque o que resta, após a análise de ambos os romances em paralelo e da somatória dos resultados analíticos de uma leitura atenta em suas memórias labirínticas e identidades moventes, é: “(...) o diabo, na rua, no meio do redemunho” (GSV, p. 262, grifo do autor) chave de leitura a respeito de como as questões de memória e identidade cultural tendem a indefinir-se.

E é notório, pelo tema do sertão e da globalização, que isso é abordado a partir das modificações sócio-históricas que os romances representam tanto no interno, quanto no externo (CANDIDO, 2006). Afinal, GSV é publicado em um período pós-guerra que permite ao homem dar vazão a seus dizeres. Já o dizer em $N N$ se desvela pela fase pós-ditadura varguista e pelo 11 de setembro que travam o contar, nublando a história dos esquecidos. Esses são os fatores de diferenciação externa que afetam as estruturações internas dos dois romances.

Por fim, a interlocução entre narrador e narratário demonstra-se como o principal elo para a leitura comparada de ambos. No entanto, o resultado é diverso, pois em GSV o narrador conta a história do 'Outro', que não deixa de ser sua própria história. Já em $N N$, para o narrador jornalista contar a própria história, precisa contar a do 'Outro'. Em outra instância narrativa, o sertanejo Manoel Perna conta a história do 'Outro' aludindo a um 'interlocutor apagado', que, também, é um 'Outro'.

GRANDE SERTÃO: VEREDAS, NOVE NOITES AND THE CONSTRUCTION OF THE "SELF" THROUGH THE "ANOTHER"

\section{ABSTRACT}

In Grande Sertão: Veredas (1962), the narrator Riobaldo alludes to an interlocutor that listen his history. In Nove Noites (2002), written by Bernardo Carvalho, one of the narrators, Manoel Perna, achieves a similar procedure because he directs his narration for an interlocutor who we do not know as well. Therefore, there is a contact point between the both novels, by which happens the formation of individual identity since the contact with the unfamiliar. In this paper, we will discuss this contact point as a 'point of suture' of Stuart Hall 
and we will present which are the effects of these interlocution through a narratological basis.

Keywords: Grande Sertão, Veredas, Nove Noites, Memories, Cultural Identity, Brazilian Literature.

GRANDE SERTÃO: VEREDAS, NOVE NOITES Y LA CONSTRUCCIÓN DEL 'YO' MEDIANTE EL “OUTRO”

\section{RÉSUMEN}

En Grande Sertão: Veredas (1962), el narrador Riobaldo se refiere a un interlocutor que escucha su historia. En Nove Noites (2002), de Bernardo Carvalho, uno de los narradores, Manoel Perna, realiza un procedimiento similar al enderezar su narración a un interlocutor a quien tampoco conocemos. Así, se evidencia un punto de contacto entre la narración de ambas las novelas del cuál adviene la formación de la identidad individual mediante el contacto con la ajena. En este artículo, discutiremos este punto de contacto a partir del 'punto de sutura', de Stuart Hall, y presentaremos los efectos deprendidos de esas interlocuciones a partir de una base teórica narratológica.

Palabras clave: Grande Sertão, Veredas, Nove Noites, Memorias, Identidad Cultural, Literatura Brasileña.

\section{NotAS}

1 A partir daqui nos referimos a Grande Sertão: Veredas como GSV e a Nove Noites como NN. Além do mais, as datas entre parênteses se referem ao ano de publicação de cada romance. As datas das edições utilizadas neste trabalho podem ser visualizadas na seção de "Referências"

2 Utilizamos o termo 'interlocutor apagado' para designarmos um interlocutor posto na narração enquanto destinatário da informação narrativa veiculada pelo 'eu' da narração. No entanto, como esse interlocutor nunca assume a voz narrativa, ele tem, por isso, sua voz contornada pela do narrador. Assim, o leitor não conhece a voz deste interlocutor, no caso a voz do 'ele', a não ser por meio da do narrador. 
3 Cremos que uma explanação acerca da focalização seja necessária para situarmos o leitor nesse procedimento técnico narrativo. A focalização é comumente conhecida como ponto de vista. Esta primeira noção diz muito a respeito de seu funcionamento, embora não o problematize. Qualquer narrador conduz a informação narrativa a partir de pontos de vista ideológico, cultural, afetivo, etc. Por isso, o narrador focaliza certos acontecimentos em detrimento de outros, dando ênfase a alguns e 'esquecendo', 'retirando' e 'diminuindo' outros, afinal o que ele conta tem a ver com interesses particulares.

4 A essa diferenciação nos referimos ao seguinte trecho de Genette (1975) "Os instantes têm nele uma forte tendência para se agruparem, para se confundirem, e essa capacidade é, evidentemente, a própria condição de experiência da $<<$ memória involuntária $>>$ (p. 123)" onde ele trata da

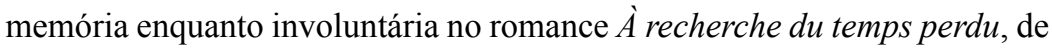
Marcel Proust. Diferentemente ocorre com as narrações de $G S V$ e $N N$, que vão em busca de memórias.

5 A respeito disso, cabe a distinção feita por Franco Baptista Sandanello (2014) entre as memórias retrospectivas, presentificativas e as prospectivas. As primeiras, retrospectivas, dizem respeito a narrativas nas quais há uma diminuição da participação efetiva do narrador para a estruturação do narrado de modo que ele reconhece os limites cognitivos relacionados à busca do passado e, assim, reforça a credibilidade com o leitor. As segundas, presentificativas, dizem respeito à ressignificação presente do passado a partir do ponto de vista atual do narrador. Aliás, este parece ser o tipo mais adequado para a classificação de $G S V$ e $N N$. Já nas últimas, as prospectivas, o narrador argumenta a respeito do passado com vistas a conseguir a complacência do leitor e, assim, conseguir atar as duas pontas da vida.

6 Essa associação só foi possível a partir da leitura da resenha História e memória, de Raimundo Nonato Pereira Moreira. As musas geradas pela relação da Mnémosine com Zeus foram: Calíope, musa da eloquência; Clio, musa da história; Érato, musa da poesia lírica; Euterpe, musa da música; Melpômene, musa da tragédia; Polímnia, musa da música sacra; Terpsícore, musa da dança; Tália, musa da comédia; e Urânia, musa da astronomia e astrologia. 
7 Isso se relaciona à memória de Quain a partir de uma fotografia tirada com vários pesquisadores contemporâneos e colegas no mesmo período em que o estadunidense estava no Xingu. No entanto, Quain é o único a não aparecer na fotografia: "Àquela altura ele ainda estava vivo entre os Krahô, e a imagem não deixa de ser, de certa forma, um retrato dele, pela ausência" $(N N$, p. 32).

8 Isso pode ser bem representado pela sensação de indefinição do seguinte trecho, narrado por Manoel Perna: "Imaginei o seu sonho e o seu pesadelo. Me disse que chegou ao Rio no Carnaval de 1938 e que conheceu, num bloco de rua, uma negra alta e vistosa, fantasiada de enfermeira. Vestia uniforme branco, chapéu branco e sapatos brancos, que realçavam a sua pele de breu, cintilante de suor. Ele mal falava português. Não entendia nada do que ela lhe dizia. Estava bêbado. Levou-a para o seu quarto de pensão, dormiram juntos, mas quando acordou no dia seguinte, ela já não estava lá, como o contador de histórias de Fiji, que o abandonava antes do nascer do sol, e no lugar da enfermeira havia um homem na sua cama, um negro forte e nu, como o nativo dos retratos que me mostrara. Já não se lembrava de nada do que acontecera, nem de como aquele homem tinha ido parar ali. Ele se exprimia por denegações" (NN, p. 127-128, grifo do autor).

9 Guimarães Rosa (2009) possui uma definição interessante de nossa identidade cultural a partir do conceito de brasilidade comentado por ele na entrevista a Günter Lorenz (p. 58-60). Para Guimarães, a identidade é tratada sob a ótica de um "sentir-pensar" que deve ser conjugado juntamente para que entendamos nossa brasilidade, além de defini-la como um reino de justiça e fundadora de religiões.

10 'I use 'identity' to refer to the meeting point, the point of suture, between on the one hand the discourses and practices which attempt to 'interpellate', speak to us or hail us into place as the social subjects of particular discourses, and on the other hand, the processes which produce subjectivities, which construct us as subjects which can be 'spoken"”.

\section{REFERÊNCIAS}

ANDRADE, Oswald de. O manifesto antropófago. In: TELES, Gilberto Mendonça. Vanguarda européia e modernismo brasileiro: apresentação e crítica 
dos principais manifestos vanguardistas. 3. ed. Petrópolis: Vozes; Brasília: INL, 1976. Disponível em: <http://www.ufrgs.br/cdrom/oandrade/oandrade. pdf $>$. Acesso em: 19 maio 2014.

ARAÚJO, Heloísa Vilhena de. Os planetas. In: A raiz da alma. São Paulo: Edusp, 1992. p. 85-101.

CANDIDO, Antonio. Literatura e Sociedade. 9. ed. Rio de Janeiro: Ouro sobre azul, 2006.

CANDIDO, Antonio. O homem dos avessos. In: ROSA, João Guimarães. Ficção Completa. Rio de Janeiro: Nova Fronteira: 2009 (Org. Eduardo Coutinho).

CARVALHO, Bernardo. Bernardo Carvalho e a literatura como antídoto da banalidade. Entrevista concedida a Marco Sanchez. Revisão de Alexandre Schossler. In: Deutsch Welle, 30/Ago/2011. Disponível em: <http://www. $\mathrm{dw}$.de/bernardo-carvalho-e-a-literatura-como-ant\%C3\%ADdoto-da-banalidade/a-15352025>. Acesso em: 10 abr. 2012.

CARVALHO, Bernardo. Nove Noites. $3^{\text {a }}$ reimpressão. São Paulo: Companhia das Letras, 2004.

GALLAGHER, Catherine. "Ficção". In: Franco Moretti (Org.). A cultura do romance. Tradução: Denise Bottmann. São Paulo: Cosac Naif, 2009. p. 629658.

GARBUGLIO, José Carlos. O demiurgo da linguagem. In: Revista Soripta, Belo Horizonte, n. 10, 2002, p. 158-176.

GENETTE, Gérard. Discurso da narrativa. Trad. Fernando Cabral Martins. 3. ed. Lisboa, Vega, 1995.

HALL, Stuart. A identidade cultural na pós-modernidade. 11. ed. Trad. Tomáz Tadeu da Silva e Guacira Lopes Louro. Rio de Janeiro: DP\&A, 2006.

HALL, Stuart; SOVIK, Liv (Org.). Da diáspora: Identidades e Mediações Culturais. Tradução de Adelaine La Guardia Resende et al. Belo Horizonte: Editora UFMG; Brasília, Editora da UNESCO no Brasil, 2003.

HALL, Stuart. Who needs identity? In: ___ GAY, Paul. Questions of cultural identity. London: Sage Publications, 2003. p. 1-35.

HUTCHEON, Linda. Metaficção historiográfica: O passatempo do tempo passado. In: . Poética do pós-modernismo: história, teoria, ficção. Trad. Ricardo Cruz. Rio de Janeiro: Imago, 1991. p. 141-162 .

MOREIRA, Raimundo Nonato Pereira. História e memória. Algumas observações. In: Praxis, n.2, Ano 2, 2005. Disponível em: <http://pablo.deassis.net. 
br/wpcontent/uploads/Hist\%C3\%B3riaeMem\%C3\%B3ria.pdf>. Acesso em: 22 jan. 2014.

OLIVEIRA, Franklin de. Revolução rosiana. In: ROSA, João Guimarães. Ficção Completa. Rio de Janeiro: Nova Fronteira, 2009. p. 103-109.

RICCEUR, Paul. A memória, a história, o esquecimento. Tradução : Alain Françoise et al. Campinas: Editora da Unicamp, 2007.

RONCARI, Luiz. As três cores do amor. In: . O Brasil de Rosa - mito e história no universo rosiano: o amor e o poder. São Paulo: Ed. Unesp, 2004. ROSA, João Guimarães. Diálogo com Guimarães Rosa. In: . Ficção Completa. Rio de Janeiro: Nova Fronteira, 2009. p. 31-65.

ROSA, João Guimarães. Grande Sertão: Veredas. 19. ed. Rio de Janeiro: Nova Fronteira, 2001.

SANDANELLO, Franco Baptista Sandanello. O escorpião e o jaguar: O memorialismo prospectivo d'O Ateneu, de Raul Pompéia. 2014. 164 fls. Tese (Doutorado em Literatura Comprarada) - Programa de Pós-Graduação em Estudos Literários, Unesp, Araraquara, 2014.

SARLO, Beatriz. Crítica do testemunho: sujeito e experiência. In:

Tempo passado: cultura da memória e guinada subjetiva. Tradução: Rosa Freire D'Aguiar. São Paulo: Companhia das Letras; Belo Horizonte: UFMG, 2007. p. 23-44.

SHAKESPEARE, William. Hamlet. Tradução: Mario Fondelli. Rio de Janeiro: Newton Compton Brasil Ltda, 1996.

Submetido em 23 de fevereiro de 2015.

Aceito em 06 de agosto de 2015.

Publicado em 21 de agosto de 2015 